\section{AGRIEKONOMIKA}

http://journal.trunojoyo.ac.id/agriekonomika

Volume 10, Nomor 1, 2021

https://doi.org/10.21107/agriekonomika.v10i1.9789
Agriekonomika has been accredited as a scientific journal by the Ministry of

Research-Technology and Higher

Education Republic of Indonesia: No.

23/E/KPT/2019

\title{
Penuaan Petani dan Determinan Penambahan Tenaga Kerja di Sektor Pertanian
}

\author{
$\llbracket$ Dini Yuniarti \& Lestari Sukarniati \\ Fakultas Ekonomi dan Bisnis, Universitas Ahmad Dahlan Yogyakarta, Indonesia
}

Received: Januari 2021; Accepted: April 2021; Published: April 2021

\begin{abstract}
ABSTRAK
Penuaan petani menjadi isu di sektor pertanian, padahal sektor pertanian memiliki posisi penting bagi Indonesia. Untuk itu perlu mengkaji fenomena tersebut dan factor yang mempengaruhi penambahan tenaga kerja di sektor pertanian. Tujuan penelitian ini untuk mengkaji bagaimana pengaruh usia, pendidikan, lahan, dan upah terhadap penambahan tenaga kerja di sektor pertanianserta kaitannya dengan penuaan petani.Jenis data yang digunakan adalah data kuantitatif. Sumber data merupakan data sekunder dengan dimensi waktu data merupakan data cross section meliputi 34 provinsi di Indonesia pada tahun 2020. Variabel dependen adalah penambahan jumlah petani, variabel independen meliputi usia, pendidikan, lahan dan upah minimum sektor pertanian. Alat analisis menggunakan regresi berganda dengan metode Ordinary Least Square. Hasil penelitian menunjukkan kelompok usia 25-59 tahun, pendidikan dasar, pendidikan menengah dan upah berpengaruh terhadap penambahan tenaga kerja, sedangkan variabel usia 15-24 tahun, pendidikan tinggi, dan lahan tidak berpengaruh terhadap penambahan tenaga kerja di sektor pertanian.
\end{abstract}

Kata kunci: Penuaan Petani, Pendidikan, Tenaga Kerja.

Aging Farmers and a Determinant of Employment Increase in the Agricultural Sector

\begin{abstract}
The aging of farmers is an issue in the agricultural sector, even though the agricultural sector has an important position for Indonesia. For this reason, it is necessary to examine this phenomenon and the factors that influence the addition of labor in the agricultural sector. The purpose of this study was to examine how age, education, land, and wages influence the addition of labor in the agricultural sector and its relation to farmer aging. The type of data used in this research is quantitative data. The data source is secondary data. The time dimension is a cross section of data covering 34 provinces in Indonesia in 2020. The dependent variable is the addition of the number of farmers, while the independent variable includes age, education, land and the minimum wage in the agricultural sector. The analysis tool uses multiple regression with the Ordinary Least Square method. The results showed that the group age 25-59 years, basic education, secondary education and wages had an effect on the addition of labor, while the variables aged 15-24 years, tertiary education, and land had no effect on the addition of labor in the agricultural sector.
\end{abstract}

Keyword: Aging Farmer, Education, Agriculture, Labour. 


\section{PENDAHULUAN}

Pandemi Covid-19 telah menyebabkan perekonomian mengalami kontraksi. Badan Pusat Statistik (BPS) mencatat pertumbuhan ekonomi Indonesia pada kuartal II dan kuartal III tahun 2020 mengalami kontraksi masing-masing mencatat sebesar 5,32\% (year on yearl yoy) pada Kuartal II dan -3,49\% (yoy) pada Kuartal III. Indonesia telah mengalami kontraksi dua kuartal berturut-turut dan mengalami resesi. Namun disaat sektorsektor lain mengalami penurunan, sektor pertanian tumbuh positif, dimana berturutturut pada kuartal pertama sampai ketiga tumbuh sebesar 0,02\% (kuartal I), 2,19\% (kuartal II) dan 2,15\% pada kuartal III. Hal ini memberikan gambaran bahwa sektor pertanian dapat menjadi penyangga pertumbuhan ekonomi di saat terjadi penurunan.

Selain mampu tumbuh positif, sektor pertanian juga selama ini menjadi sector yang paling banyak menyerap tenaga kerja. Laporan Badan Pusat Statistik Agustus 2020 menyebutkan penduduk yang bekerja di sektor pertanian sebanyak 29,7 persen, meningkat dibandingkan tahun 2019 sebesar 27,53 persen, setelah sempat mengalami penurunan dari tahun 2018 ke tahun 2019 (Gambar 1). Hal ini sejalan dengan Adriani and Wildayana (2015) yang menyatakan peran sektor pertanian dimana pertambahan produksi sector pertanian akan mendorong peningkatan kesempatan kerja pertanian, angkatan kerja sebesar di pasar tenaga kerja pertanian. Selain itu adanya pertambahan produksi sektor pertanian akan mendorong peningkatan pendapatan nasional sektor pertanian dan investasi di pasar produk pertanian.

Namun, ada beberapa masalah tenaga kerja yang berkaitan dengan sektor pertanian. Salah satunya adalah penurunan jumlah rumah tangga petani. Berdasarkan Sensus Pertanian tahun 2013, terdapat pengurangan jumlah rumah tangga petani dibandingan dengan Sensus Pertanian Tahun 2003. Gambar 2 menunjukkan adanya penurunan sebanyak 5.096.715 rumah tangga petani di tahun 2013, setelah sebelumnya pada Sensus Pertanian tahun 2003 terdapat 31,2 juta rumah tangga petani kemudian berkurang pada Sensus Pertanian tahun 2013 menjadi 25,1 juta rumah tangga.

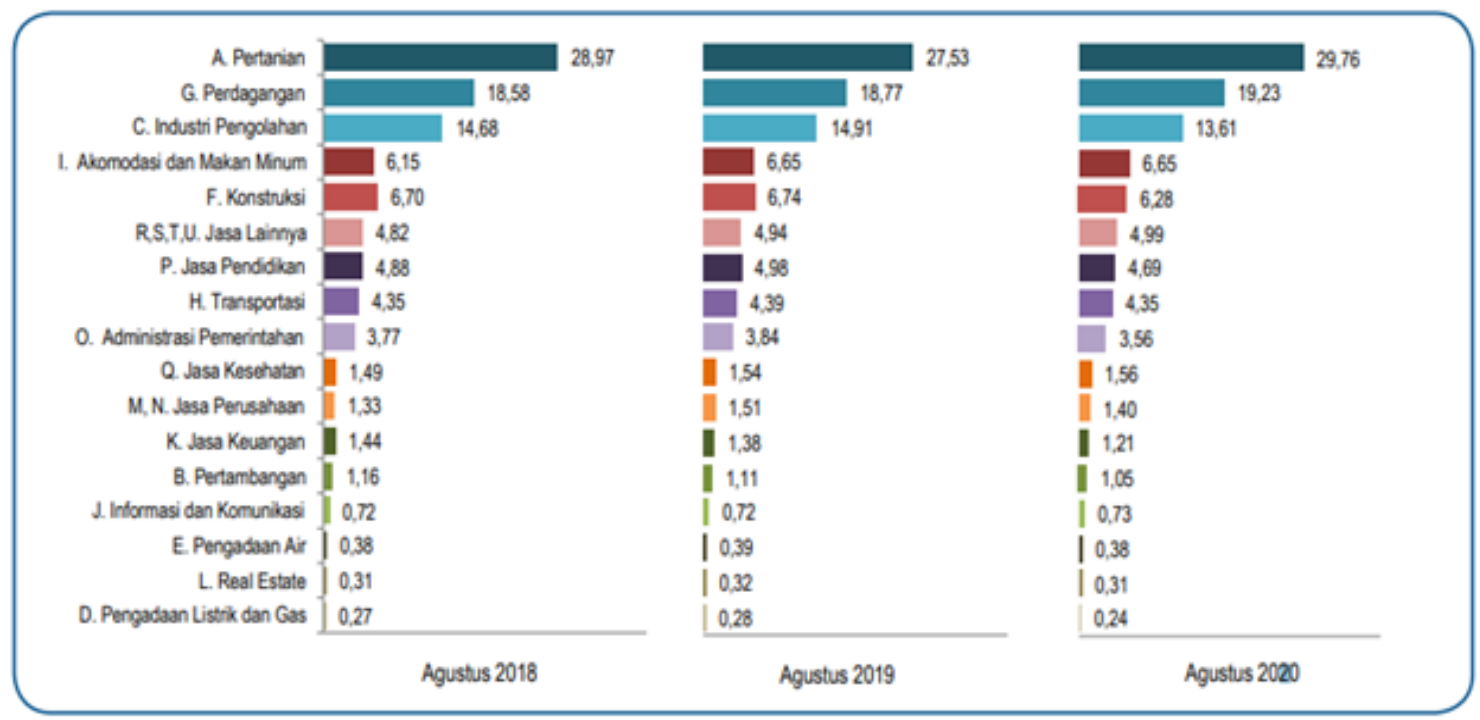

Sumber: Badan Pusat Statistik, (2020a)

\section{Gambar 1}

Persentase Penduduk Bekerja Menurut Lapangan Pekerjaan Utama, Februari 2018-Februari 2020 


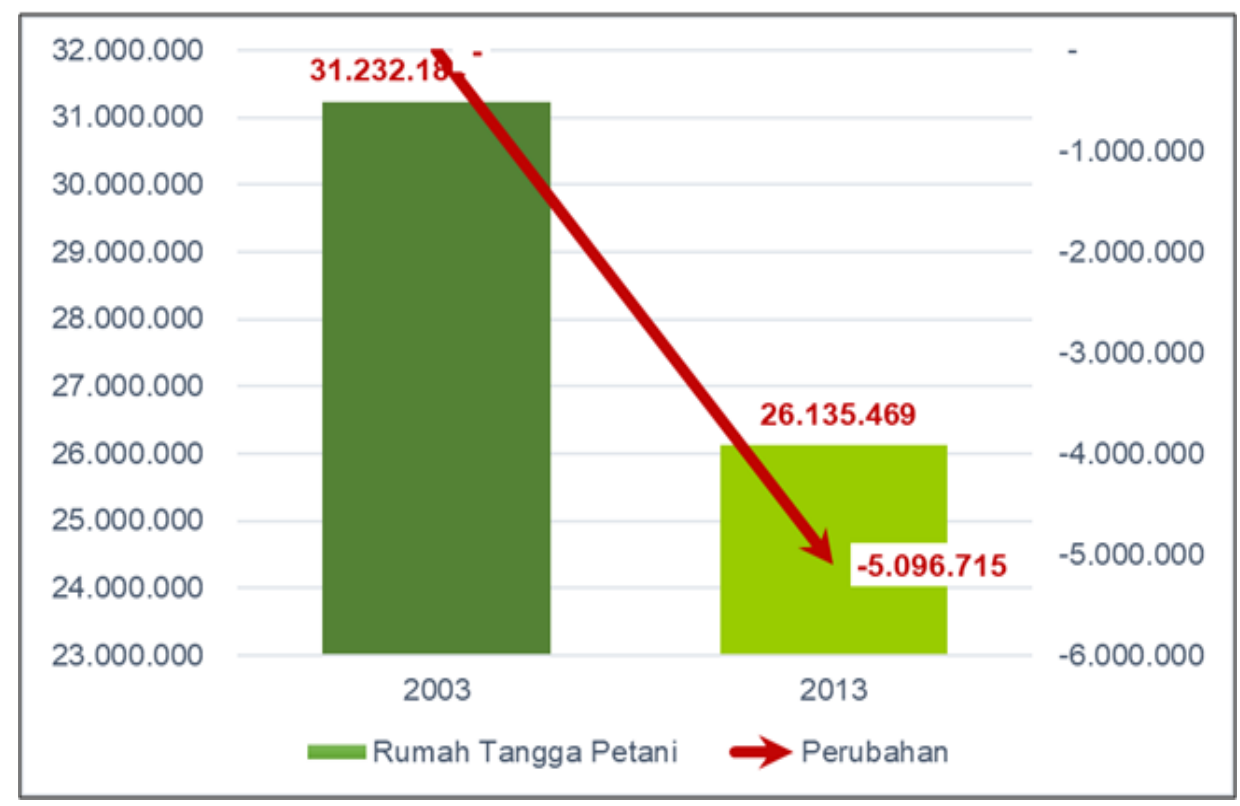

Sumber: Badan Pusat Statistik (2014)

Gambar 2

\section{Perubahan Rumah Tangga Petani antar Sensus 2003 dan 2013}

Menurunnya jumlah rumah tangga petani menurut White (2012), adalah adanya ketidaktertarikan dari pemuda terhadap sektor pertanian di pedesaan. Lebih lanjut White (2015), menyatakan bahwa tidak ditemukan contoh wirausaha generasi baru, petani muda yang inovatif di 12 desa di Indonesia. Hal ini sejalan dengan apa yang dinyatakan oleh Arvianti dkk (2018), bahwa terdapat perubahan di ketenagakerjaan pertanian yaitu perubahan struktur demografi yang kurang menguntungkan. Susilowati (2016a) ,menyebut petani berusia tua semakin berkurang, sedangkan petani muda juga semakin berkurang. ini merupakan fenomena aging farmer yaitu fenomena jumlah petani muda terus mengalami penurunan, baik secara absolut maupun relatif, sementara petani usia tua semakin meningkat. Wiyono (2015), menyatakan bahwa usia petani pun sudah menua, sementara proses regenerasi berjalan sangat lambat terutama pada sektor tanaman pangan. Generasi muda lebih memilih bekerja di sektor industri daripada sektor pertanian. Selain itu orang tua usaha tani padi juga tidak menginginkan anaknya menjadi petani. Hal yang berbeda ditunjukkan oleh petani hortikultura yang lebih banyak yang menginginkan anaknya menjadi petani.

Fenomena ini menjadi ancaman bagi sektor pertanian. Apalagi secara keseluruhan pembangunan pertanian di Indonesia menurut Dewi dkk. (2016), memiliki posisi penting bagi pembangunan nasional. Hal ini didasari oleh potensi sumber daya alam yang besar dan beragam, besarnya pangsa terhadap pendapatan nasional dan ekspor nasional. Pangsa sektor pertanian terhadap PDB menempati posisi kedua terbesar yaitu $14,27 \%$ (Badan Pusat Statistik, 2021b). Selanjutnya penduduk Indonesia yang menggantungkan hidupnya pada sektor ini sangat besar, bahkan menempati urutan pertama, dimana 29,59 juta jiwa bekerja di sektor pertanian (Badan Pusat Statistik, 2021a). Selain itu pertanian juga berperan dalam penyediaan pangan masyarakat. Proyeksi penduduk Indonesia pada tahun sekitar 305,6 jutapada tahun 2035(Badan Pusat Statistik, 2013). Hal ini mempunyai konsekuensi logis bagi pemenuhan pangan di Indonesia, untuk mendukung 
ketahanan pangan. Ketersedian pangan merupakan salah satu dari pilar ketahanan pangan, selain akses, utilisasi dan stabilitas. Sektor pertanian merupakan sektor yang mendukung ketersediaan pangan tersebut.Indonesia sendiri pada tahun 2020 berada pada peringat ke 65 dari 113 negara dalam Laporan Global Food Secutiy Index,posisinya masih di bawah negara ASEAN lainnya seperti Singapura (19), Malaysia (43), Thailand (51) dan Vietnam (63). Lebih lanjut Indeks Ketahanan Pangan (IKP) Indonesia Tahun 2020 menunjukkan masih ada 66 kabupaten $(15,8 \%)$ dari 416 kabupaten, 4 kota $(4 \%)$ dari 98 kota dan 2 provinsi $(5,88 \%)$ dari 34 provinsi masuk dalam kategori IKP rendah. Hal ini secara umum terjadi terutama di Wilayah Indonesia bagian timur (Badan Ketahanan Pangan, 2020). Oleh karena saat petani yang menjadi ujung tombal sektor pertanian mengalami masalah, dalam jangka panjang akan mempengaruhi produksi pertanian, dan nantinya mengancam ekonomi nasional, ketenagakerjaan dan ketahanan pangan di Indonesia.

Apabila hal ini tidak dibarengi dengan adanya regenerasi yang sepadan dapat berakibat pada semakin sulitnya sektor pertanian untuk kembali meningkat. Untuk itu perlu dikaji mengenai determinan penambahan tenaga kerja di sektor pertanian. Faktor apa yang mempengaruhi tenaga kerja terhadap sektor pertanian. Beberapa studi mengkaji faktor-faktor yang mempengaruhi penyerapan tenaga kerja di sektor pertanian. Faktor-faktor tersebut meliputi pendidikan (Poerwono \& Khaafidh, 2013; Prasetya \& Putro, 2019; Nurdiyanto dkk., 2020), usia petani (Poerwono \& Khaafidh, 2013; Tulangow dkk., 2017; Prasetya \& Putro, 2019), upah (Tulangow dkk., 2017; Halim dkk., 2015; Dewi dkk., 2016; Hasibuan dkk., 2019), lahan (Tulangow dkk., 2017); (Halim dkk., 2015); (Dewi dkk., 2016); (Khaafidh \& Poerwono, 2013), dan pendapatan (Khaafidh \& Poerwono, 2013); (Berk, 2018); (Halim dkk., 2015); (Dewi dkk., 2016).
Faktor-faktor tersebut menjadi beberapa faktor utama yang berpengaruh terhadap penyerapan tenaga kerja di sektor pertanian. Selain studi yang mengkaji faktor-faktor yang mempengaruhi penyerapan tenaga kerja di sektor pertanian, juga telah dilakukan penelitian yang berfokus pada penyerapan tenaga kerja di sektor pertanian berusia muda dan determinan yang mempengaruhinya yang telah dilakukan antara lain oleh Agwu, dkk. (2014), Bezu dan Holden (2014), Berk (2018), Susilowati (2016) serta Choudhsary dan Choudhary (2013).

Akan tetapi, penelitian yang menggunakan analisis determinan tenaga kerja di sektor pertanian yang mengkhususkan pada pembagian kelompok berdasar usia dan pendidikan sejauh ini belum banyak ditemukan. Untuk itu menarik melakukan kajian tenaga kerja di sektor pertanian dengan melihat pengaruh kelompok usia dan kelompok pendidikan. Studi ini mengkaji pengaruh pendidikan dan usia dengan membaginya secara lebih rinci menjadi beberapa kelompok. Hal ini untuk melihat pengaruh setiap kelompok tersebut secara spesifik. Pengelompokan usia terdiri dari tiga kelompok yaitu usia 15-24 tahun, kelompok 25-59 tahun dan kelompok diatas 60 tahun. Pembagian kelompok ini berdasarkan konsep dan definisi yang digunakan dalam Statistik Ketenagakerjaan Sektor Pertanian (Kementan, 2020). Hal ini diharapkan dapat mengidentifikasi adanya fenomena aging farmer di Indonesia. Untuk pendidikan sendiri terdiri dari pendidikan dasar, pendidikan menengah dan pendidikan tinggi. Selain usia dan pendidikan, studi ini juga mengkaji faktor lain yang mempengaruhi penambahan tenaga kerja di sektor pertanian, yaitu luas lahan dan upah.

\section{METODE PENELITIAN}

Penelitian ini bertujuan untuk menguji hipotesis, yaitu untuk menguji apakah terdapat hubungan mendasar dan menjawab pertanyaan penelitian yang diajukan. Penelitian ini menggunakan 
jenis data kuantitatif. Sumber data dalam penelitian ini adalah data sekunder yang berasal dari Statistik Ketengekerjaaan Petani (Kementan, 2020) dan Badan Pusat Statistik. Dimensi waktu dari data berupa data cross section meliputi 34 provinsi di Indonesia pada tahun 2020. Variabel dependen dalam penelitian ini merupakan penambahan jumlah petani, sedangkan variabel independen meliputi usia tenaga kerja yang dibagi menjadi kelompok usia 15-24 tahun, usia 25-59 tahun, dan usia di atas 60 tahun. Variabel pendidikan meliputi menjadi pendidikan dasar, pendidikan menengah dan pendidikan tinggi. Variabel lainnya yaitu luas lahan dan upah minimum sektor pertanian.

Untuk menganalisis pengaruh pendidikan, usia, luas lahan dan upah terhadap penambahan tenaga kerja di sektor pertanian, studi ini menggunakan regresi berganda dengan metoda Ordinary Least Square/OLS. Model regresi linier sebagai berikut:

$$
\begin{aligned}
P= & \beta 0+b_{1} U 1+b_{2} U 2+b_{3} U 3+\beta_{4} D+ \\
& b_{5} M+\beta_{6} T+b_{7} L+b_{8} U P+\varepsilon
\end{aligned}
$$

Dimana $\mathbf{P}$ merupakan Penambahan jumlah petani (orang), $\beta_{0}$ adalah konstanta, $\mathbf{b}_{1}, \mathbf{b}_{2}, \mathbf{b}_{3,}, \mathbf{b}_{4}, \mathbf{b}_{5}, \mathbf{b}_{6}, \mathbf{b}_{7}, \mathbf{b}_{8}$ adalah koefesienregresi, $\mathbf{U}_{1}$ adalah jumlah petani kelompok usia 15-24 tahun, $\mathbf{U}_{2}$ adalah kelompok usia 25-59 tahun, $\mathbf{U}_{3}$ adalah kelompok usia 60 tahun ke atas, D adalah jumlah petani dengan pendidikan dasar, $\mathbf{M}$ adalah jumlah petani dengan pendidikan menengah, $\mathbf{T}$ merupakan jumlah petani dengan pendidikan tinggi, $\mathbf{L}$ adalah luas lahan, UP merupakan upah minimum sektor pertanian, dan $\varepsilon$ adalah error term.

\section{HASIL DAN PEMBAHASAN}

Penelitian ini merupakan penelitian kuantitatif dengan menggunakan data sekunder. Dimensi waktu dari data merupakan cross section meliputi 34 provinsi yang ada di Indonesia pada tahun 2020. Data yang digunakan meliputi variabel dependen berupa penambahan tenaga kerja di sektor pertanian. Variabel independen meliputi luas lahan pertanian per provinsi, upah minimum regional sektor pertanian per provinsi, usia dibagi menjaid tiga kelompok terdiri dari kelompok usia 15-24 tahun, 25-59 tahun dan kelompok 60 tahun ke atas. Namun untuk kelompok usia 60 tahun ke atas dikeluarkan dari model karena tidak memenuhi asumsi multikolinearitas karena memiliki nilai VIF jauh di atas 10. Untuk variabel pendidikan meliputi pendidikan dasar, pendidikan menengah dan pendidikan. tinggi Alat analisis menggunakan regresi berganda dengan metode Ordinary Least Square.

Sebelum menjelaskan hasil estimasi regresi determinan tenaga kerja di sektor pertanian, maka dilakukan uji asumsi klasik, berupa uji normalitas, uji heteroskedastisitas, dan multikolinearitas. Hasil uji normalitas menggunakan uji Jarque-Bera menunjukkan nilai Chi Square5,002 lebih kecil dibandingakn Chi Square tabel 5,9915 df 2, alpha 5\%, sehingga dapat disimpulkan bahwa model memenuhi asumsi normalitas. Untuk uji heteroskedastitas menggunakan uji Glejser. Tabel 1 menunjukkan hasil uji Glejser, dimana dari semua variabel independen tidak berpengaruh signifikan pada $\alpha 5 \%$. Hal ini menunjukkan bahwa model telah memenuhi asumsi homoskedastisitas.

Table 1 Uji Heteroskedastisitas

\begin{tabular}{lc}
\hline \multicolumn{1}{c}{ Variabel } & t hitung \\
\hline Usia15_24 & $-0,290$ \\
Usia25_59 & $-1,091$ \\
Pendidikan dasar & 1,139 \\
Pendidikan mengengah & $-1,486$ \\
Pendidikan tinggi & $-0,051$ \\
Lahan & $-0,369$ \\
Upah & 1,844 \\
\hline
\end{tabular}

Sumber: Data Diolah

Nilai VIF untuk masing-masing variabel di bawah 10, sehingga memenuhi kriteria asumsi tidak adanya multikolinearitas, kecuali untuk variabel kelompok usia 25-59 tahun sebesar 11,2 tapi tetap dimasukan ke model (Tabel 2). 
Tabel 2

Uji Multikolinearitas

\begin{tabular}{lc}
\hline Variabel & VIF \\
\hline Usia15_24 & 1,4 \\
Usia25_59 & 11,2 \\
Pendidikan dasar & 9,0 \\
Pendidikan mengengah & 6,9 \\
Pendidikan tinggi & 4,1 \\
Lahan & 7,9 \\
Upah & 1,2 \\
\hline
\end{tabular}

Sumber: Data Diolah

Tabel 3, menyajikan hasil estimasi regresi determinan tenaga kerja sektor pertanian di 34 provinsi Indonesia. Nilai F statistic adalah 58,92 signifikan pada $\alpha 5 \%$, sehingga dapat dinyatakan bahwa secara simultan variabel lahan, upah, pendidikan dasar, pendidikan menengah, pendidikan tinggi, kelompok usia 1524 tahun, kelompok usia 25-59 tahun berpengaruh terhadap penambahan tenaga kerja di sektor pertanian. Untuk koefisien determinasi adjusted $\mathrm{R}^{2}$ sebesar 0,888 , menunjukkan $88,8 \%$ perubahan pada penambahan tenaga kerja di sektor pertanian dapat dijelaskan oleh variabel independen, selebihnya $11,25 \%$ dijelaskan oleh variabel lain di luar model.
Pengaruh variabel secara parsial menunjukkan bahwa, variabel usia kelompok 25-59 tahun dan pendidikan menengah berpengaruh positif terhadap penambahan jumlah tenaga kerja di sektor pertanian. Selain itu pendidikan dasar dan upah minimum sektor pertanian berpengaruh negatifterhadap penambahan tenaga kerja di sektor pertanian. Untuk variabel usia 15-24 tahun, pendidikan tinggi dan luas lahan tidak berpengaruh terhadap penambahan tenaga kerja di sektor pertanian. Penjelasan dan diskusi pengaruh setiap variabel akan dijelaskan di bawah ini.

\section{Usia}

Pengaruh usia dibedakan menjadi dua kelompok, yaitu kelompok usia 15-24 tahun dan kelompok 25-59 tahun. Kelompok usia yang berpengaruh terhadap penambahan tenaga kerja di sektor pertanian adalah kelompok usia 25-59 tahun. Oleh karena itu kelompok usia 25-59 yang lebih dominan mengalami peningkatan. Faktor usia berpengaruh terhadap tenaga kerja di sektor pertanian konsisten dengan penelitian dari Poerwono \& Khaafidh (2013), Twumasi dkk. (2019) dan Prasetya \& Putro (2019). Hal ini menunjukkan jika

Table 3

Hasil Estimasi Regresi Berganda Determinan Tenaga Kerja Sektor Pertanian

\begin{tabular}{lcccc}
\hline Variabel & Koefisien & Koefisien beta & $\begin{array}{c}\text { Kesalahan } \\
\text { Standar }\end{array}$ & t Stat \\
\hline (Constant) & 22401.727 & 12276.602 & & 1.825 \\
usia15_24 & 0,013 & 0,019 & 0,046 & 0,666 \\
usia25_59 & 0,055 & 0,009 & 1,200 & $6,148^{*}$ \\
Pendidikan_dasar & $-0,726$ & 0,378 & $-0,336$ & $-1,919^{*}$ \\
Pendidikan_mengenah & 0,070 & 0,041 & 0,264 & $1,718^{* *}$ \\
Pendidikan-tinggi & $-0,006$ & 0,004 & $-0,192$ & $-1,626$ \\
Luas lahan & $-0,011$ & 0,022 & $-0,080$ & $-0,491$ \\
Upah minimum pertanian & $-0,009$ & 0,005 & $-0,105$ & $-1,661^{* *}$ \\
R-squared & 0,912 & & & \\
Adj R-squared & 0,888 & & & \\
F sta (7, 26) & 38,5 & & & \\
Jarque-Bera & 5,002 & & & \\
Keterangan : ${ }^{*}$ Signifikan pada $\alpha=5 \% ;{ }^{* *}$ signifikan pada $\alpha=10 \%$ & \\
Sumber: Data Diolah & &
\end{tabular}


terdapat penambahan tenaga kerja di usai 25-59 akan meningkatkan tenaga kerja di sektor pertanian. Hal ini mengandung arti bahwa penambahan usia petani berada di rentang usia 25-59. Temuan yang berbeda untuk kelompok usia 15-24, meski memiliki koefisien positif namun tidak berpengaruh signifikan. bisa menjadi indikasi adanya aging farmer, karena kelompok usia muda 15-24 tahun tidak berpengaruh terhadap penambahan tenaga kerja di sektor pertanian. Kelompok 15-24 tahun didefinisikan oleh UNESCO ditetapkan sebagai usia pemuda (United Nations, 2008). Temuan yang menunjukkan berpengaruhnya kelompok usia 25-59, sedangkan disisi lain kelompok 15-25 tahun tidak berpengaruh, bisa menjadi indikasi adanya aging farmer. Studi Guo dkk. (2015), di China menunjukkan adanya fenomena aging farmer, dimana rata-rata usia petani adalah 56,6 tahun. Untuk di Indonesia sendiri laporan dari LIPI pada tahun 2017 menunjukkan rata-rata usai petani di Indonesia 45 tahun, bahkan di Jawa Tengah adalah 52 tahun.Pada tahun 2020 jumlah kelompok usia 15-24 tahun yang bekerja di sektor pertanian hanya 3,3 juta bandingkan dengan kelompok 25-59 sebanyak 24,31 juta dan di atas 60 tahun sebesar 7,38 juta (Badan Pusat Statistik, 2020a).

\section{Pendidikan}

Sama halnya dengan usia, maka untuk variabel pendidikan dikelompokan menjadi tiga bagian yaitu pendidikan dasar, pendidikan menengah dan pendidikan tinggi. Hasil estimasi menunjukan bahwa kelompok pendidikan dasar berpengaruh negatifdansignifikanterhadappenambahan tenaga kerja di sektor pertanian. Artinya semakin bertambahnya tenaga kerja dengan pendidikan dasar justru akan menurunkan penambahan tenaga kerja di sektor pertanian. Hal ini dimungkinkan karena penduduk berpendidikan rendah cenderung untuk melakukan migrasi. Pada tahun 2019 sebanyak 32,7\% orang tidak memiliki ijazah dan lulus sekolah dasar melakukan migrasi menurut data
Susenas 2019 (Badan Pusat Statistik, 2019). Kelompok pendidikan menengah menunjukkan temuan sebaliknya yaitu memiliki pengaruh positif dan signifikan. Hal ini menunjukkan bahwa penambahan tenaga kerja di sektor pertanian didukung oleh tenaga kerja dengan pendidikan menengah. Beberapa studi menunjukkan pengaruh pendidikan terhadap tenaga kerja di sektor pertanian yaitu Agwu dkk. (2012), Poerwono \& Khaafidh (2013), Prasetya \& Putro (2019), (Twumasi dkk., 2019) dan Nurdiyanto dkk. (2020). Untuk kelompok pendidikan tinggi, memiliki koefisien negatif tapi tidak berpengaruh signifikan terhadap penambahan tenaga kerja di sektor pertanian. Adanya penambahan tenaga kerja berpendidikan tinggi tidak memberikan pengaruh terhadap sektor pertanian. Hal ini menurut Sukamdi (2013), berdasarkan teori modal manusia, pendidikan memberikan kesempatan untuk memilih pekerjaan yang lebih beragam. Artinya ketika seseorang memiliki pendidikan yang lebih baik maka akan meningkatkan kesempatan untuk memilih pekerjaan di berbagai sektor, sehingga pilihan menjadi lebih banyak selain di sektor pertanian.

\section{Upah}

Variabel lain yang berpengaruh signifikan adalah upah, dengan koefisien negatif, hal ini mengandung arti ketika terjadi peningkatan upah justru akan mengurangi penambahan tenaga kerja di sektor pertanian. Hal ini dimungkinkan karena dengan upah minimum yang meningkat maka pihak yang mempekerjakan petani akan mengurangi permintaan terhadap tenaga kerja, sehingga akan mengurangi penambahan tenaga kerja. Hal ini disebabkan mayoritas petani Indonesia adalah petani gurem yaitu rumah tangga pertanian pengguna lahanyang menguasai lahan pertanian kurang dari 0,50 ha. Jumlah petani gurem di Indonesia berdasarkan Hasil Survei Pertanian Antar Sensus Sutas 2018 sebanyak 15, 8 juta rumah tangga (Badan Pusat Statistik, 2018). Hal ini akan menyebabkan pendapatan petani rendah 
karena tidak memenuhi skala ekonomi. Hal ini juga yang memungkinkan sektor pertanian didominasi pekerja keluarga $(10,1$ juta) dan berusaha sendiri sebanyak 5,12 juta. Adapun buruh atau karyawan hanya 2,56 juta dan berusaha dibantu buruh tetap atau dibayar hanya 0,82 juta (Kementan, 2020). Artinya di sektor pertanian masih didominasi oleh pekerja keluarga dan berusaha sendiri. Hal ini dimungkinkan karena keuntungan di sektor pertanian yang rendah dan tidak menentu tergantung dari kondisi alam dan harga komoditas pertanian yang fluktuatif.Selain itu menurunnya jumlah petani saat upah di sektor pertanian meningkat, karena upah di sektor lain lebih tinggi dibandingkan sektor pertanian. Hal ini menyebabkan tenaga kerja lebih tertarik bekerja di sektor lain. Data menunjukkan dari tujuh belas kategori pekerjaan utama, rata-rata upah/ gaji/pendapatan bersih sektor Pertanian, Kehutanan, dan Perikanan sebesar Rp. 1,36 juta, terendah diantara sektor-sektor yang lain, misalnya sektor Jasa Keuangan dan Asuransi sebesar 4,14 juta sebagai sektor dengan upah/gaji/pendpatan bersih tertinggi (Badan Pusat Statistik, 2020a). Temuan ini konsisten dengan penelitian Tulangow dkk. (2017), Halim dkk. (2015), Dewi dkk. (2016), dan Hasibuan dkk. (2019), yang menemukan adanya pengaruh upah terhadap penyerapan tenaga kerja di sektor pertanian. Studi Tulangow dkk. (2017), menemukan bahwa upah yang rendah di sektor pertanian mendorong terjadinya migrasi tenaga kerja sektor pertanian ke sektor nonpertanian. Meskipun menurut studi Adriani (2013), upah bukan merupakan penentu dalam peningkatan permintaan tenaga kerja terdidik dan tidak terdidik di sektor pertanian dan non pertanian.

\section{Lahan}

Luas lahan pertanian yang ada di setiap provinsi memiliki koefisien negatif dan tidak berpengaruh terhadap penambahan tenaga keja di sektor pertanian. Artinya perluasan lahan tidak mampu meningkatkan tambahan tenaga kerja. Hal ini dimungkinkan oleh adanya keterbatasan akses petani terutama petani muda terhadap lahan (Bezu \& Holden, 2014), karena tidak semua petani merupakan pemilik lahan. Studi Anandita \& Patria (2017) menyatakan penurunan jumlah petani disebabkan oleh status kepemilikan lahan yang dipengaruhi oleh kesejahteraan petani di Indonesia secara umum rendah. Dengan kata lain jika terdapat kepemilikan lahan akan mempengaruhi keputusan individu untuk bekerja pada kegiatan pertanian, seperti dinyatakan oleh studi Khaafidh (2016). Hal ini juga dinyatakan oleh White (2015), bahwa ketidakmerataan kepemilikan tanah menjadikan petani muda tidak memiliki prospek yang realistik untuk menjadi seorang petani.

Temuan yang menarik dari estimasi determinan penambahan tenaga kerja di sektor pertanian adalah adanya indikasi aging farmer, dimana kelompok usia 1524 tahun tidak memiliki pengaruh terhadap penambahan tenaga kerja. Temuan ini didukung data dari Badan Pusat Statistik (2020) yang menunjukkan pada tahun 2020 jumlah penduduk usia 15-24 tahun yang bekerja di sektor pertanian mempunyai proporsi paling kecil yaitu 3,3 juta jiwa, dibandingkan petani di usia 25-59 tahun sebanyak 24,31 juta jiwa dan kelompok di atas 60 tahun yaitu 7,38 juta jiwa. Hal ini tentunya akan memberikan dampak yang serius bagi sektor pertanian yang berkelanjutan. Adanya penurunan petani usia muda akan berpengaruh terhadap keberlanjutan produksi pangan, padahal disisi lain kebutuhan akan pangan akan terus mengalami peningkatan. Hal ini akan menyebabkan Indonesia akan mengalami masalah ketahanan pangan (Dewi dkk., 2016; Yodfiatfinda, 2020).

Kondisi seperti ini bukan hanya terjadi di Indonesia, namun juga di negaranegara lain seperti di India (Choudhary \& Choudhary, 2013), di Slovenia, pemuda, perempuan dan berpendidikan lebih menyukai bekerja di sektor nonpertanian (Bojnec dkk., 2003). Studi di Ethiopia Selatan hanya $9 \%$ pemuda di desa berencana bekerja di sektor 
pertanian sebagai penghidupan, hal ini disebabkan ketiadaan akses terhadap lahan (Bezu \& Holden, 2014). Berbeda dengan di Turki, petani muda keluar dari sektor pertanian, karena jumlah anak, kedekatan rumah dengan pusat kota, serta pendapatan. Petani muda memiliki prioritas kehidupan yang baik bagi anakanak seperti pendidikan dan layanan kesehatan (Berk, 2018). Menurut Salvago dkk. (2019), petani terutama petani muda memiliki keinginan untuk menjadi petani di Prachinburi Province, Thailand jika ada opportunity yang lebih baik untuk memulai pertanian.

Untuk kasus di Indonesia menurut Susilowati (2016), penyebab menurunnya minat tenaga kerja muda di sektor pertanian, diantaranya adalah citra sektor pertanian yang kurang bergengsi, berisiko tinggi, kurang memberikan jaminan tingkat stabilitas, dan kontinyuitas pendapatan; rata-rata penguasaan lahan sempit; diversifikasi usaha non-pertanian dan industri pertanian di desa kurang/tidak berkembang; suksesi pengelolaan usaha tani rendah; belum ada kebijakan insentif khusus untuk petani. Studi Tulangow dkk. (2017), menemukenali adanya migrasi tenaga kerja dari ektor pertanian ke nonpertanian karena berkurangnya lahan pertanian, upah di sektor pertanian yang rendah, faktor usia, dan pekerjaan di sektor non-pertanian lebih menjanjikan, selain itu setelah berpindah pekerjaan dari sektor pertanian ke non-pertanian tenaga kerja merasa nyaman bekerja di sektor non pertanian. Lebih lanjut menurut Arvianti dkk. (2018), terjadinya krisis generasi muda di sektor pertanian karena sebagain besar orangtua di daerah pedesaan tidak menginginkan anaknya bekerja sebagai petani.

Berdasarkan studi-studi yang telah dilakukan, maka dapat ditarik benang merah penyebab pemuda kurang berminat dengan sektor pertanian yaitu citra sektor pertanian itu sendiri yang kurang menarik, karena tidak menjanjikan kehidupan yang lebih pasti, akses terhadap lahan yang dimiliki pemuda terbatas, dan kebijakan insentif khusus untuk petani sehingga sektor pertanian kurang berkembang. Menilik penyebab berkurangya minat pemuda terhadap sektor pertanian karena citra sektor pertanian tersebut kurang menarik dan menjanjikan kehidupan yang pasti baik bagi pemuda itu sendiri maupun bagi orangtua, maka perlu dilakukan upaya untuk menarik tenaga kerja muda agar mau menggeluti pertanian. Menurut Susilowati (2016), strategi yang perlu dilakukan adalah mengubah persepsi generasi muda bahwa sektor pertanian sebagai sektor yang menarik. Adanya pengembangan agroindustri, inovasi teknologi, pemberian insentif khusus kepada petani muda, modernisai pertanian, disertai pelatihan dan pemberdayaan petani muda akan memberikan dampak baik bagi citra sektor pertanian bagi kaum muda, serta memperkenalkan pertanian kepada generasi muda sejak dini. Studi Setiawan, Nugraha, dan Rasiska (2019), menunjukkan contoh baik bagiamana pemuda-pemuda di kawasan Desa Cisondari, Bandung dapat mengembangkan sektor pertanian berupa pertanian organik yang mampu menarik pemuda untuk tetap berada di daerah pedesaan. Karakteristik petani, adanya inovasi, dan faktor lingkungan menjadi faktor paling dominan yang menentukan pemuda untuk tetap tinggal di desa.

Selain itu petani di Indonesia juga menghadapi masalah lain, menurut Badan Pusat Statistik (2020), pendidikan tenaga kerja sektor pertanian masih didominasi tingkat pendidikan dasar yaitu sebesar $84,22 \%$, pendidikan menengah $14,03 \%$, sedangkan pendidikan tinggi hanya $1,76 \%$. Hal tersebut menurut Arvianti et al (2018) menyebabkan produktivitas petani Indonesia lebih rendah dibandingkan dengan negara-negara di ASEAN. Padahal menurut Saparyati (2008) dalam mengembangkan wilayah ada tiga komponen utama yang berperan yaitu sumber daya alam, sumber daya manusia, dan tehnologi. Pendidikan mengambil dua dari hal tersebut yaitu sumberdaya manusia dan teknologi. Masih rendahnya 
pendidikan petani di Indonesia yang didominasi oleh pendidikan dasar akan berdampak kepada pengembangan sektor pertanian itu sendiri. Berkaitan dengan pendidikan dan teknologi hal ini sejalan dengan laporan FAO (2014), tentang petani pemuda dan pertanian, dimana terdapat enam tantangan petani muda di sektor pertanian, dimana salah satunya adalah keterbatasan akses terhadap pengetahuan. Tantangan lainnya meliputi akses terhadap lahan, akses terhadap jasa keuangan, kesulitan mengakses green job, keterbatasan akses pasar, dan kurangnya keterlibatan pemuda dalam penentuan kebijakan.

\section{SIMPULAN}

Sektor pertanian memiliki posisi yang strategis bagi perekonomian dan ketahanan pangan. Adanya fenomena aging farmer dan rendahnya pendidikan petani menjadi dua masalah yang melekat pada sektor pertanian. Untuk itu perlu diketahui determinan yang mempengaruhi penambahan tenaga kerja di sektor pertanian. Hasil studi menguatkan indikasi terjadinya aging farmer di Indonesia, dimana kelompok usia muda yaitu 1524 tahun tidak berpengaruh terhadap penambahan tenaga kerja di sektor pertanian, sedangkan kelompok usia 25-59 tahun berpengaruh postif. Selain itu ditemukenali bahwa pendidikan dasar berpengaruh negatif, sedangkan pendidikan menengah berpengaruh positif. Upah minimum sektor pertanian menjadi determinan lain tenaga kerja di sektor pertanian. Berdasarkan uraian di atas perlu disusun kebijakan untuk mengatisipasi berlanjutnya aging farmer, yaitu dengan merubah persepsi pemuda terhadap sektor pertanian. Untuk itu perlu dilakukan upaya meningkatkan citra sektor pertanian itu sendiri agar menarik bagi pemuda melalui beberapa pendekatan. Pertama, meningkatkan harkat dan martabat sektor pertanian menjadi sektor yang menjanjikan.
Pemerintah dapat melakukan program peningkatan kesejahteraan petani, melalui kebijakan yang pro terhadap petani dan memperbaiki akses pasar. Kedua, melalui pendekatan pendidikan mengenai pertanian yang berkelanjutan, perbaikan keterampilan, pengetahuan dan inovasi pertanian. Ketiga adanya dukungan dalam pembiayaan bagi petani berkaitan dengan tingkat keuntungan, risiko yang tinggi dan kepemilian agunan yang rendah menyebabkan penyaluran kredit terhadao sektor pertanian tidak setinggi sektor lain. Untuk itu perlu adanya political will bagi pembiayaan sektor pertanian, salah satunya adalah subsidi bagi petani dan akses terhadap jasa keuangan. Keempat, keberpihakan kepada petani dengan mengurangi impor bahan pangan yang diproduksi di dalam negari, apalagi saat terjadi surplus. Terakhir, melalui sosialisasi secara masif kepada pemuda mengenai prospek menjanjikan sektor pertanian dan keberhasilan para petani serta pelibatan pemuda dalam penentuan kebijakan.

\section{UCAPAN TERIMA KASIH}

Ucapan terimakasih kami tujukan kepada Lembaga Penelitian dan Pengembangan Masyarakat (LPPM) Universitas Ahmad Dahlan yang telah mendukung pendanaan, sehingga penelitian dapat terlaksana.

\section{DAFTAR PUSTAKA}

Adriani, D., \& Wildayana, E. (2015). Integrasi Pertumbuhan Ekonomi Dan Penciptaan Kesempatan Kerja Sektor Pertanian Di Indonesia. Sosiohumaniora, 17(3), 269. https:// doi.org/10.24198/sosiohumaniora. v17i3.8381.

Agwu, N. M., Nwankwo, E. E., \& Anyanwu, C. I. (2012). Determinants of Agricultural Labour Participation among Youths in Abia State, Nigeria. International Journal of Food and Agricultural Economics, 2(1), 157164. 
Anandita, D. A., \& Patria, K. Z. (2017). Agriculture Challenges: Decline of Farmers and Farmland (Study from Indonesian Family Life Survey). Jurnal IImu Ekonomi Dan Pembangunan, 16(1). https://doi. org/10.20961/jiep.v16i1.2314.

Arvianti, E. Y., Masyhuri, Waluyati, L. R., \& Darwanto, D. hadi. (2018). Gambaran Krisis Petani Muda di Indonesia. Jurnal Sosial Ekonomi Dan Kebijakan Pertanian, 7(2), 176-187. https://doi.org/https:// doi.org/10.21107/agriekonomika. v8i2.5429 ABSTRAK.

Badan Ketahanan Pangan. (2020). Indeks Ketahanan Pangan 2020. Badan Ketahanan Pangan.

Badan Pusat Statistik. (2013). Proyeksi Penduduk Indonesia 2010-2035 (Vol. 90, Issue 6). https://doi.org/10.1007/ BF00830441

Badan Pusat Statistik. (2014). Potensi Pertanian Indonesia Analisis Hasil Pencacahan Lengkap Sensus Pertanian 2013.

Badan Pusat Statistik. (2018). Hasil Survei Pertanian Antar Sensus Sutas 2018.

Badan Pusat Statistik. (2019). Profil Migran Hasil Survei Sosial Ekonomi nasional 2019.

Badan Pusat Statistik. (2020a). Keadaan Ketenagakerjaan Indonesia Agustus 2020 (Issue 86).

Badan Pusat Statistik. (2020b). Keadaan Ketenagakerjaan Indonesia Februari 2020. In Berita Resmi Statistik (Issue 40).

Badan Pusat Statistik. (2021a). Booklet Sakernas Survei Angkatan Kerja Nasional 2021 (Vol. 1).
Badan Pusat Statistik. (2021b). Statistik Pertumbuhan Ekonomi Indonesia Triwulan IV-2020. Www.Bps.Go.ld, 36, 1-12. https://www.bps.go.id/ pressrelease/2020/02/05/1755/ ekonomi-indonesia-2019-tumbuh-502-persen.html

Berk, A. (2018). Factors affecting the exit from farming of young farmers in Turkey: the case of Niğde province. Ciência Rural, 48(8), 1-8. https:// doi.org/he case of Niğde province. http://dx.doi.org/10.1590/01038478cr20180471

Bezu, S., \& Holden, S. (2014). Are Rural Youth in Ethiopia Abandoning Agriculture? World Development, 64, 259-272. https://doi.org/10.1016/j. worlddev.2014.06.013

Bojnec, S., Dries, L., \& Swinnen, J. F. M. (2003). Human Capital And Labor Flows Out Of The Agricultural Sector: Evidence From Slovenia. Proceedings of the 25th International Conference of Agricultural Economists (IAAE), August, 649654.

Choudhary, H. R., \& Choudhary, A. (2013). Why Indian Farmers and Rural Youth Are Moving From Farming. Popular Kheti, 2(2), 60-66.

Dewi, R. F., Prihanto, P. H., \& Edy, J. K. (2016). Analisis penyerapan tenaga kerja pada sektor pertanian di Kabupaten Tanjung Jabung Barat. Ekonomi Sumberdaya Dan Lingkungan, 5(1), 19-25.

FAO. (2014). Youth and agriculture :Key challenges and concrete solutions Published. 
Guo, G., Wen, Q., \& Zhu, J. (2015). The Impact of Aging Agricultural Labor Population on Farmland Output: From the Perspective of Farmer Preferences. Mathematical Problems in Engineering, 2015. https://doi. org/10.1155/2015/730618

Halim, F. Z., Hamzah, A., \& Sofyan. (2015). Faktor-Faktor Yang Mempengaruhi Penyerapan Tenaga Kerja. Jurnal IImu Ekonomi, 3(1), 27-36.

Hasibuan, P. A. H., Ginting, R., \& Effendi, I. (2019). Faktor-Faktor yang Mempengaruhi Penyerapan Tenaga Kerja Pada Sektor Pertanian di Sumatera Utara. AGRISAINS: Jurnal IImiah Magister Agribisnis, 1(1), 1017.

Kementan. (2020). Statistik Ketenagakerjaan Sektor Pertanian (Februari 2018).

Khaafidh, M., \& Poerwono, D. (2013). Faktor-Faktor Yang Mempengaruhi Keputusan Tenaga Kerja Untuk Bekerja Di Kegiatan Pertanian (Studi Kasus: Kabupaten Rembang). Diponegoro Journal of Economics, 2(2), 1-13. https://ejournal3. undip.ac.id/index.php/jme/article/ view/2908

Nurdiyanto, E., Sukamdi, \& Rofi, A. (2020). Partisipasi Tenaga Kerja Pemuda di sektor Pertanian di Sulawesi tengah. Analisis Kebijakan Pertanian, 18(2), 135-150.

Prasetya, N. R., \& Putro, S. (2019). Hubungan Tingkat Pendidikan dan Umur Petani dengan Penurunan Jumlah Rumah Tangga Usaha Pertanian Sub Sektor Tanaman Pangan di Desa Meteseh Kecamatan Boja Kabupaten Kendal. Edu Geography, 7(1), 47-56.
Salvago, M. R., Phiboon, K., Faysse, N., Phuoc, T., \& Nguyen, L. (2019). Young people' $s$ willingness to farm under present and improved conditions in Thailand. Outlook on Agriculture, 48(4), 282-291. https:// doi.org/10.1177/0030727019880189

Saparyati, D. W. I. I. (2008). Kajian Peran Pendidikan terhadap Pembangunana Pertanian di Kabupaten Demak.

Setiawan, I., Nugraha, A., \& Rasiska, S. (2019). Go urban or stay rural : determinants of young farmers staying in or leaving agricultural field ( a case study in Cisondari , West Java , Indonesia ) Go urban or stay rural: determinants of young farmers staying in or leaving agricultural field ( a case. Conference on Sustainability Science 2018. https://doi.org/10.1088/17551315/306/1/012033.

Sukamdi. (2013). Struggling out of Recession The Influence of Crisis on Economic Performance and Welfare in Java [Nijmegen (NE)] Radboud University Nijmegen]. https://repository.ubn.ru.nl/bitstream/ handle/2066/ 112930/112930. pdf? sequence $=1$.

Susilowati, S. H. (2016a). Fenomena Penuaan Petani Dan Berkurangnya Tenaga Kerja Muda Serta Implikasinya Bagi Kebijakan Pembangunan Pertanian. Forum Penelitian Agro Ekonomi, 35(1), 3555. 
Susilowati, S. H. (2016b). Kebijakan Intensif untuk Petani Muda: Pembelajaran dari Berbagai Negara dan Implikasinya bagi Kebijakan di Indonesia Incentive Policy for Young Farmers: Lesson Learned from Various Countries and the Implications for Indonesian Policy. Forum Penelitian Agro Ekonomi, 34(2), 103-123.

Tulangow, N. N., Waney, N. F. L., \& Timban, J. F. J. (2017). Migrasi Tenaga Kerja Dari Sektor Pertanian Ke Non Pertanian Di Desa Tatelu Kecamatan Dimembe. Agri-Sosioekonomi, 13(3A), 191. https://doi.org/10.35791/ agrsosek.13.3a.2017.18170.

Twumasi, M. A., Jiang, Y., \& Acheampong, M. O. (2019). Determinants of agriculture participation among tertiary institution youths in Ghana. Journal of Agricultural Extension and Rural Development, 11(March), 56-66. https://doi.org/10.5897/ JAERD2018.1011.
White, B. (2012). Agriculture and the Generation Problem: Rural Youth , Employment and the Future of Farming. 43(6).

White, B. (2015). Generational dynamics in agriculture: Reflections on rural youth and farming futures. Cahiers Agricultures, 24(6), 330-334. https:// doi.org/10.1684/agr.2015.0787

Wiyono, S. (2015). Regenerasi Petani.

Yodfiatfinda. (2020). Effort to Improve the Interests of Young Generations in the Agricultural Sector to Attain Food Security in Indonesia. 5th International Conference on Food, Agriculture and Natural Resources (FANRes 2019) Effort, 194(FANRes 2019), 291-296. 